AWEJ for Translation \& Literary Studies Volume, 1 Number 3, August 2017

Pp.78-85

DOI: http://dx.doi.org/10.24093/awejtls/vol1no3.6

\title{
Ecofeminism in Doris Lessing's Mara and Dann: An Adventure
}

\author{
Najla R. Aldeeb \\ Language Center, Batterjee Medical College \\ Jeddah, Saudi Arabia
}

\begin{abstract}
Doris Lessing's Mara and Dann: An Adventure (1999) is a fantasy novel with focus on nature. Lessing portrays a world in which oppression by a male-dominated society is at the root of countless problems. It depicts the effects of global warming in the future emphasizing that the domination of women is the core of all crises in the environment. The novel implies that women are able to lead as most of the female characters in the novel play the role of the leader starting from Daima, the woman who protects Mara and Dann as children, to Orphne the woman who heals Dann from addiction. Applying Greta Claire Gaard's (1993) principles of ecofeminism to literature classifies and justifies the cause of the movement (p. 20). This paper sheds light on Gaard's four types of ecofeminism in Lessing's Rama and Dann: An Adventure: liberal, culture, social and socialist by discussing the apocalypses, patriarchal legacy, pathetic fallacy and radical orthodoxies as features of ecofeminism.
\end{abstract}

Key words: apocalypses, ecofeminism, pathetic fallacy, patriarchal legacy, radical orthodoxies

Cite as: Aldeeb, N. R. (2017). Ecofeminism in Doris Lessing's Mara and Dann: An Adventure. Arab World English Journal for Translation \& Literary Studies, 1(2).

DOI: http://dx.doi.org/10.24093/awejtls/vol1no3.6 